\title{
Model-Based Interpretation of Groundwater Arsenic Mobility during in Situ Reductive Transformation of Ferrihydrite
}

Stolze, Lucien; Zhang, Di; Guo, Huaming; Rolle, Massimo

Published in:

Environmental Science and Technology

Link to article, DOI:

10.1021/acs.est.9b00527

Publication date:

2019

Document Version

Peer reviewed version

Link back to DTU Orbit

Citation (APA):

Stolze, L., Zhang, D., Guo, H., \& Rolle, M. (2019). Model-Based Interpretation of Groundwater Arsenic Mobility during in Situ Reductive Transformation of Ferrihydrite. Environmental Science and Technology, 53(12), 68456854. https://doi.org/10.1021/acs.est.9b00527

\section{General rights}

Copyright and moral rights for the publications made accessible in the public portal are retained by the authors and/or other copyright owners and it is a condition of accessing publications that users recognise and abide by the legal requirements associated with these rights.

- Users may download and print one copy of any publication from the public portal for the purpose of private study or research.

- You may not further distribute the material or use it for any profit-making activity or commercial gain

- You may freely distribute the URL identifying the publication in the public portal 
This is a Post Print of the article published online $22^{\text {nd }}$ May 2019 in Environmental Science \& Technology. The publishers' version is available at the permanent link:

https://pubs.acs.org/doi/10.1021/acs.est.9b00527

\section{Model-based interpretation of groundwater arsenic mobility during in-situ reductive transformation of ferrihydrite}

Lucien Stolze ${ }^{1}$, Di Zhang ${ }^{2}$, Huaming Guo ${ }^{2}$, Massimo Rolle*1

${ }^{1}$ Department of Environmental Engineering, Technical University of Denmark, Miljøvej, Building 115, 2800 Kgs. Lyngby, Denmark

${ }^{2}$ School of Water Resources and Environment, China University of Geosciences, Beijing 100083, China

*Corresponding author phone: +45 45252257; email: masro@env.dtu.dk

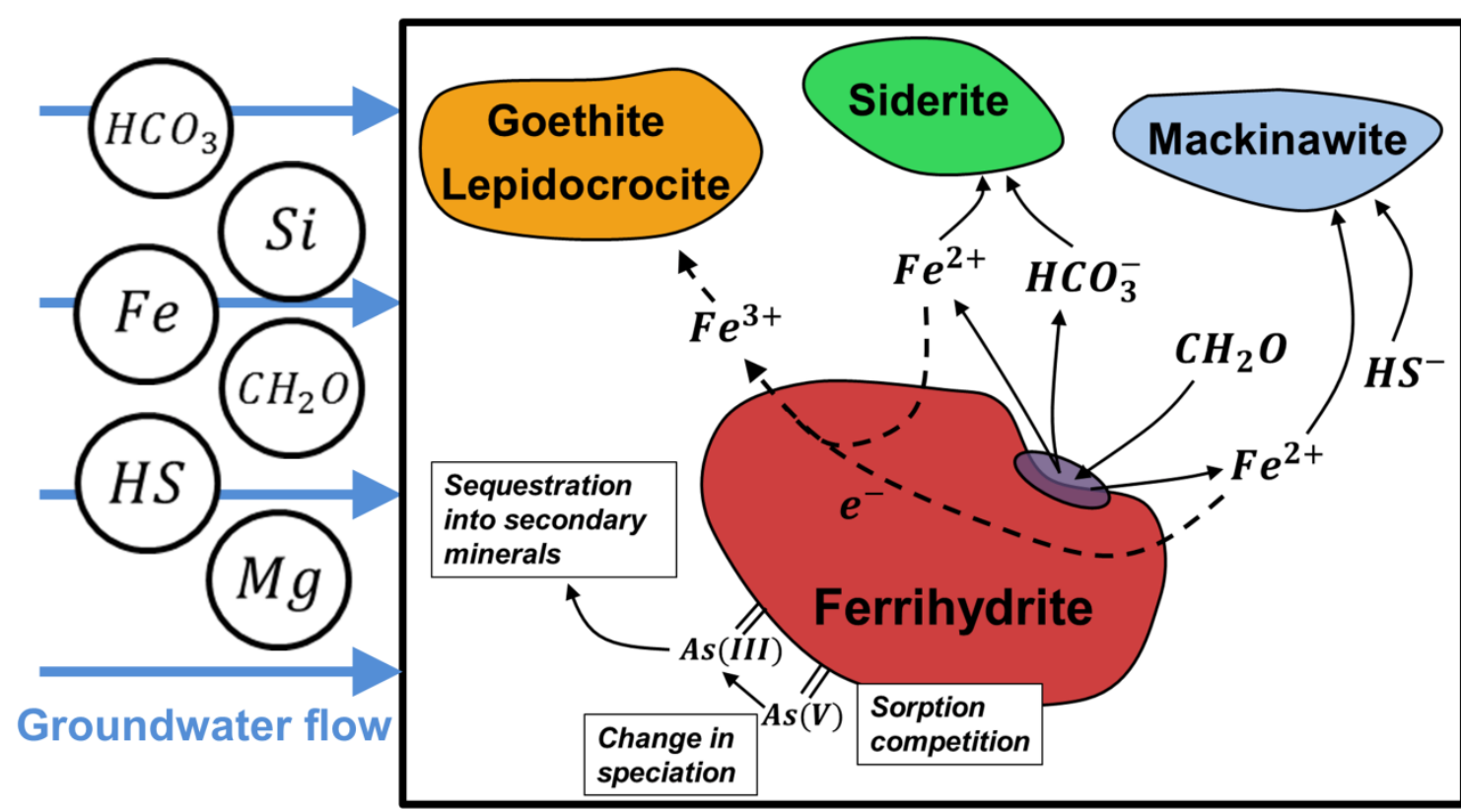




\section{Abstract}

1 Arsenic (As) release and mobility in groundwater is coupled to the iron (Fe) cycling and the

2 associated transformation of Fe-oxides present in sediments. Recent in-situ experiments have

3 provided observations on arsenic mobilization and co-occurring reductive mineral transformation

4 when placing As-loaded ferrihydrite-coated sand for 80 days in wells of an As-contaminated

5 aquifer of Northern China. However, the complex temporal change in solid-associated arsenic

6 and the multiple geochemical processes occurring when the flowing groundwater contacts the

7 As-loaded ferrihydrite-coated sand hamper a detailed evaluation of the experimental dataset. In

8 this study, we develop a modeling approach that allows a quantitative interpretation of arsenic

9 release and ferrihydrite transformation observed during the in-situ experiments. The model

10 accounts for the interplay of abiotic and biotic geochemical processes (i.e., surface complexation,

11 reductive dissolution, formation of secondary iron minerals and arsenic sequestration into the

12 newly formed minerals) involved in the transformation of Fe-oxides and controlling arsenic

13 mobility. The results show the capability of the proposed approach to reproduce the temporal

14 trends of solid arsenic and ferrihydrite concentrations, as well as the spatial variability of mineral

15 transformation, observed in different wells using a common set of surface complexation

16 parameters and kinetic rate constants. The simulation outcomes allowed us to disentangle the

17 specific contribution of the different mechanisms controlling the release of arsenic. It was

18 possible to identify an initial rapid but minor release of As $(13-23 \%$ of the initial surface

19 concentration) due to desorption from ferrihydrite, as well as the reduction of adsorbed $\mathrm{As}(\mathrm{V})$ to

$20 \mathrm{As}(\mathrm{III})$ upon contact with the flowing anoxic groundwater. Successively, reductive dissolution of

21 ferrihydrite caused the decrease of the amount of the $\mathrm{Fe}$ mineral phase and led to a major

22 depletion of solid-associated arsenic. The produced Fe(II) catalyzed the ferrihydrite conversion 
23 into more crystalline Fe(III) oxides (i.e., lepidocrocite and goethite) through Ostwald ripening, 24 and resulted in the formation of siderite and mackinawite upon reaction with carbonates and 25 sulfides naturally present in the groundwater. The model results also showed that, whereas the 26 decrease in surface sites during reductive dissolution of ferrihydrite promoted arsenic 27 mobilization, the mineral transformation limited As release through its sequestration into the 28 newly formed secondary mineral phases.

29 
31 Prolonged exposure to arsenic (As) contaminated groundwater affects the health of millions of

32 individuals in various parts of the world (1-3). This problem is particularly severe in South East

33 Asia (4) where arsenic contamination primarily results from the reducing conditions prevailing in

34 the aquifers, triggering the dissolution of iron oxides present in the sediments and the

35 simultaneous release of As (5-8). The mobility of arsenic in groundwater is controlled by iron

36 minerals through sorption onto the mineral surfaces (9-13). Other important processes, such as

37 the reduction of arsenate to arsenite, can change the affinity for mineral surfaces and affect

38 arsenic mobility (14-16).

39 Significant effort has been devoted to the investigation of the cycling of iron oxides and its

40 fundamental implications on arsenic release and transport. Ferrihydrite, which has a high

41 capacity in hosting arsenic (17), has been detected in sediments of Bangladesh (18-19) and near-

42 surface sediments in the Mekong Delta (20) where groundwater arsenic contamination occurred.

43 This poorly crystalline oxide is reactive and can undergo microbially-mediated reductive 44 dissolution (21-22). Furthermore, ferrihydrite can adopt, over time, a more crystalline structure

45 (e.g., goethite), which causes a decrease in the As sequestration potential of the sediments (13).

46 The ferrous iron produced during the reductive dissolution of ferrihydrite can (i) abiotically

47 catalyze the crystallization of the Fe(III) oxide phases (23-26) and/or (ii) precipitate into $\mathrm{Fe}(\mathrm{II})$ -

48 bearing mineral phases such as siderite, mackinawite, vivianite $(12,21,27)$. Depending on the

49 type of secondary mineral phases, significant amount of arsenic can be sequestered through

50 adsorption and reincorporation leading to a disparity between the disintegration of ferrihydrite

51 and the arsenic release (28-32). 
52 The interpretation and prediction of arsenic fate in the subsurface is particularly challenging as it

53 requires the consideration of the complex interplay between flow, reactive transport processes

54 and the hydrochemistry of the groundwater. Despite the large number of studies on arsenic

55 release and transport mechanisms an apparent research gap still exists between the level of

56 understanding of arsenic mobility under controlled laboratory conditions and under natural field

57 conditions. Laboratory studies typically limit the number of geochemical processes under

58 investigation using simplified aqueous composition and mineral assemblage. In contrast, natural

59 systems have a higher level of complexity due to the large number of geochemical factors and

60 co-occurring mechanisms. Hence, pilot-scale experiments, directly conducted in aquifer systems,

61 are of primary importance to bridge such knowledge gap between simplified laboratory setups

62 and complex field investigations. Recently performed pilot-scale experiments, injecting reactive

63 organic compounds to stimulate microbial activity in the subsurface, have provided insights on

64 the transformation of naturally-occurring mineral phases and their interactions with arsenic (33-

65 34). Another experimental approach that has been adopted in pilot scale experiments consists in

66 assessing the change of known mineral phases exposed to natural groundwater conditions (33,

67 36-38). Furthermore, important insights and quantitative understanding of arsenic release and

68 transport processes are obtained when experimental observations are interpreted with numerical

69 modelling both at laboratory (39-42) and at field scales (34, 43-45).

70 In this study, we develop a model to simulate the reductive transformation of synthetic

71 ferrihydrite and concomitant release of pre-loaded arsenic exposed to natural groundwater

72 conditions during in-situ experiments performed in an As-contaminated sedimentary aquifer of

73 Northern China (37). Such experiments have shown complex dynamics between arsenic release

74 from ferrihydrite-coated sand and ferrihydrite dissolution/transformation at different spatial 
75 locations. Using the implemented modeling framework, we provide a quantitative interpretation

76 of the experimental datasets comprising (i) time series of total $\mathrm{Fe}$ and As solid-associated

77 concentrations, (ii) mineral composition at the end of the experiments and (iii) groundwater

78 hydrochemical data. The modeling outcomes highlight the distinct contribution and the

79 interactions of different geochemical processes controlling the mobilization of arsenic at the field

80 site. Such processes include surface complexation reactions, microbially-mediated reductive

81 dissolution, mineral transformation through Ostwald ripening, formation of secondary mineral

82 phases and As sequestration in the newly formed minerals, and determine the complex trends of

83 arsenic and iron observed at the field site.

\section{$84 \quad$ Materials and Methods}

\section{Experiments and datasets description}

86 The in-situ experiments were conducted in monitoring wells screened in a shallow reducing As-

87 contaminated aquifer in the Hetao Basin (Inner Mongolia, China) and consisted in placing As-

88 loaded synthetic iron mineral phases at screen depth (i.e., [18.5 - 26.2] m) for 80 days in order to

89 observe the effect of the continuous groundwater flow on the As retention and iron mineral

90 transformation. The ferrihydrite coated sand was synthetized according to the method of

91 Schwertmann and Cornell (46) and the As loading was performed in the laboratory by using a

92 solid-to-solution ratio of $50 \mathrm{~g} / \mathrm{L}$ and equilibrating the solid phase with a $500 \mathrm{mg} / \mathrm{L} \mathrm{As}(\mathrm{V})$

93 solution. The As-loaded coated sand had a porosity of 0.5 , a Fe content of $2.71 \mathrm{mg} / \mathrm{g}$ coated sand

94 (i.e., $27 \mathrm{~g}$ ferrihydrite/L) and an As content of $213 \mu \mathrm{g} / \mathrm{g}$ coated sand. 
95 The coated sand was divided into amounts of $0.5 \mathrm{~g}$ before being deployed in the field, where 96 water could flow homogeneously through the highly permeable porous medium. Periodic 97 sampling of the solid phase allowed measuring the temporal change in solid-associated As and 98 total Fe content after total digestion of the sample, using the microwave-assisted method of Link et al. (47). Reductive dissolution of ferrihydrite and release of arsenic occurred incongruently in 100 all wells as shown by the monitored transient decrease in Fe and As. Synchrotron X-Ray 101 diffraction (XRD) indicated that goethite formation occurred in all wells whereas presence of 102 lepidocrocite was less pronounced and differed among the wells. The difference in mineral phase 103 composition was confirmed by the scanning electron microscopy (SEM) exhibiting varying 104 degree of crystallization. In order to characterize the mineral phase composition and the As 105 oxidation at the end of the experiments, Fe and As K-edge X-Ray absorption spectroscopy 106 (XANES) was conducted at the BL14W beamline of the Shanghai Synchrotron Radiation 107 Facility (SSRF) operated in the energy range $[-50 ; 150 \mathrm{eV}]$ with a $\mathrm{Si}(111)$ monochromator. Fe 108 K-edge XANES indicated significant formation of siderite and mackinawite during the 109 experiments. As K-edge XANES showed that the oxidation state of As adsorbed onto the 110 ferrihydrite surface partially changed from $\mathrm{As}(\mathrm{V})$ to $\mathrm{As}(\mathrm{III})$. During the in-situ experiments, the 111 chemical composition of the groundwater was measured at 0,30 and 80 days in each well. In this 112 study, we consider the datasets collected in 3 wells placed along the main groundwater flow 113 direction and separated by a distance of $2.5 \mathrm{~km}$. The datasets include the average groundwater 114 composition for each well, the temporal change in solid-associated As and Fe, as well as the 115 quantification of the secondary mineral phases at the end of the experiments. Details about the 116 monitoring wells and field data are provided in the Supporting Information, whereas an extensive 117 description of the in-situ experiments is given by Zhang et al. (37). 


\section{Modeling approach}

119 The model simulates the groundwater flow through the ferrihydrite-coated sand leading to a 120 change from aerobic to anaerobic conditions, the continuous supply of dissolved groundwater 121 species, the mineral transformation, and the As release/sequestration. Figure 1 displays the

122 location of the 3 considered wells, and a visual representation of the conceptual framework for 123 the proposed approach and of the key biogeochemical processes. The model accounts for a series 124 of processes triggered by the dynamic change in the hydrochemistry: the microbially-driven 125 reductive dissolution of ferrihydrite, the formation of secondary $\mathrm{Fe}(\mathrm{II})$ and $\mathrm{Fe}(\mathrm{III})$ oxides mineral 126 phases, the change in As redox state, as well as the uptake of As through sorption onto iron oxide 127 surfaces and sequestration into secondary mineral phases.

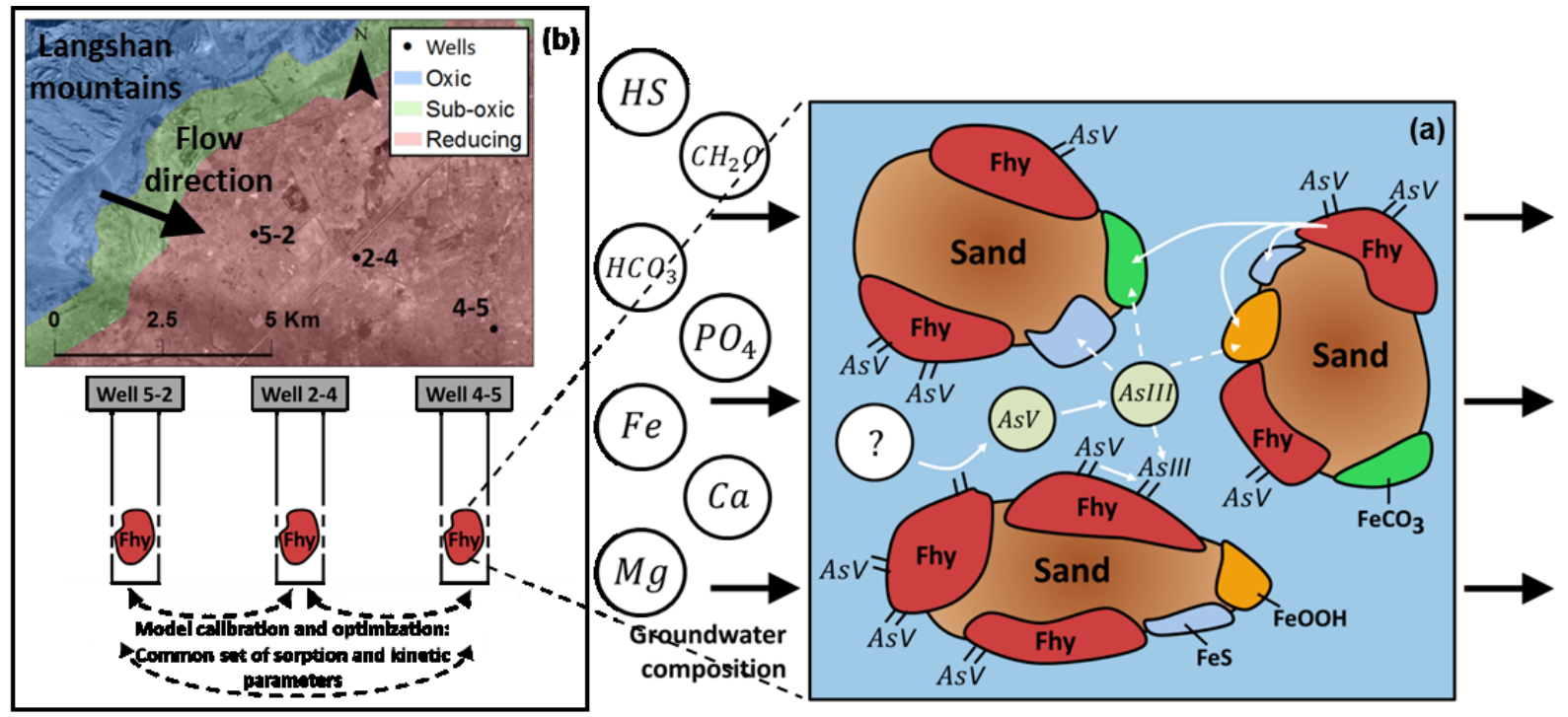

129 Figure 1. Illustration of the modeling approach for reductive transformation of ferrihydrite and 130 As mobilization/sequestration during the in-situ experiments: (a) conceptual model; (b) location 131 of the observation wells and simultaneous calibration approach through parallelization of 132 simulations with a common set of parameters for the different spatial locations. 
133 The first modeling steps consist in loading the arsenic onto the mineral surface by equilibrating 134 ferrihydrite with the As concentrated solution used for the preparation of the reactive samples, 135 and defining the hydrochemical composition of the groundwater according to the field 136 measurements. Subsequently, the solution in contact with the As-loaded ferrihydrite is iteratively 137 replaced by the groundwater solution to simulate the flushing of the pores due to groundwater 138 advection. The flow rates defined through the advective time steps were based on values found in 139 Stolze et al. (45) showing decreasing flow velocity along the flow line from the mountains 140 towards the flat plain (Supplementary Information, Table SI7). Following the transport step, the 141 surface complexation reactions and aqueous speciation are calculated assuming local equilibrium, 142 whereas the reductive dissolution of ferrihydrite, the transformation and precipitation of mineral 143 phases, and the change in As speciation were described as kinetic processes. Therefore, the 144 feedback/interaction of the flow and transport processes with the reaction network is directly 145 taken into account in the description of the flow-through system.

146 The model was implemented by coupling the geochemical code PHREEQC-3 (48) with the 147 software MATLAB $^{\circledR}$ (49-50) using the IPhreeqc model (51-52). Such coupling results in a 148 flexible modeling approach that combines the capabilities of PHREEQC to model solute 149 transport, kinetic and equilibrium reactions with the advanced capability and functions of 150 MATLAB $^{\circledR}$ for data analysis, model calibration and optimization. We used the WATEQ4F 151 thermodynamic aqueous reactions database, amended with the aqueous speciation reactions of 152 arsenic from Dixit and Hering (17) (Table 1). 


\section{Reaction network}

155 The model includes a series of abiotic and microbially-mediated reactions that aimed at 156 describing the geochemical transformations taking place during the in-situ experiments. Table 1

157 lists the key reactions considered in the model. Ferrihydrite was represented with its simplified 158 stoichiometry $\mathrm{Fe}(\mathrm{OH})_{3}$ for computational ease (21). Secondary $\mathrm{Fe}(\mathrm{III})$ phases (i.e., goethite and 159 lepidocrocite) were represented as a generic $\mathrm{Fe}(\mathrm{III})$ oxide $(\mathrm{FeOOH})$.

Table 1: Aqueous speciation and geochemical reactions included in the reactive transport model

\begin{tabular}{|c|c|c|}
\hline Aqueous speciation & & $\log K$ \\
\hline $\mathrm{AsO}_{4}^{3-}+3 \mathrm{H}^{+}=\mathrm{H}_{3} \mathrm{AsO}_{4}$ & & $20.06^{(\mathrm{a})}$ \\
\hline $\mathrm{AsO}_{4}^{3-}+2 \mathrm{H}^{+}=\mathrm{H}_{2} \mathrm{AsO}_{4}^{-}$ & & $18.35^{(\mathrm{a})}$ \\
\hline $\mathrm{AsO}_{4}^{3-}+\mathrm{H}^{+}=\mathrm{HAsO}_{4}^{2-}$ & & $11.60^{(\mathrm{a})}$ \\
\hline $\mathrm{AsO}_{3}^{3-}+3 \mathrm{H}^{+}=\mathrm{H}_{3} \mathrm{AsO}_{3}$ & & $34.74^{(\mathrm{a})}$ \\
\hline $\mathrm{AsO}_{3}^{3-}+2 \mathrm{H}^{+}=\mathrm{H}_{2} \mathrm{AsO}_{3}^{-}$ & & $25.52^{(\mathrm{a})}$ \\
\hline $\mathrm{AsO}_{3}^{3-}+\mathrm{H}^{+}=\mathrm{HAsO}_{3}^{2-}$ & & $13.41^{(\mathrm{a})}$ \\
\hline Reactive minerals & Name & $\log K$ \\
\hline $\mathrm{Fe}(\mathrm{OH})_{3}+3 \mathrm{H}^{+}=\mathrm{Fe}^{3+}+3 \mathrm{H}_{2} \mathrm{O}$ & Ferrihydrite & $4.891^{(b)}$ \\
\hline $\mathrm{FeOOH}+3 \mathrm{H}^{+}=\mathrm{Fe}^{3+}+2 \mathrm{H}_{2} \mathrm{O}$ & Fe(III) oxide & $-1^{(\mathrm{c})}$ \\
\hline $\mathrm{FeS}+\mathrm{H}^{+}=\mathrm{Fe}^{2+}+\mathrm{HS}^{-}$ & Mackinawite & $-2.95^{(\mathrm{d})}$ \\
\hline $\mathrm{FeCO}_{3}=\mathrm{Fe}^{2+}+\mathrm{CO}_{3}^{2-}$ & Siderite & $-10.89^{(\mathrm{c})}$ \\
\hline
\end{tabular}

Reductive dissolution of ferrihydrite

$\mathrm{CH}_{2} \mathrm{O}+4 \mathrm{Fe}(\mathrm{OH})_{3}+7 \mathrm{H}^{+} \rightarrow \mathrm{HCO}_{3}^{-}+4 \mathrm{Fe}^{2+}+10 \mathrm{H}_{2} \mathrm{O}$

Redox change in As speciation

$0.5 \mathrm{CH}_{2} \mathrm{O}+\mathrm{HAsO}_{4}^{2-}+1.5 \mathrm{H}^{+} \rightarrow \mathrm{H}_{3} \mathrm{AsO}_{3}+0.5 \mathrm{HCO}_{3}^{-}$

$0.5 \mathrm{CH}_{2} \mathrm{O}+\mathrm{Hfo}_{\mathrm{w}} \mathrm{AsO}_{4}^{-2}+1.5 \mathrm{H}^{+} \rightarrow \mathrm{Hfo}_{\mathrm{w}} \mathrm{H}_{2} \mathrm{AsO}_{3}+0.5 \mathrm{HCO}_{3}^{-}$

(a) (17), based on MINEQL+ database (53); ${ }^{\text {(b) }}$ (54), ${ }^{\text {(c) }}(55),{ }^{\text {(d) }}$ (56)

161 Dissolution and precipitation kinetics. The mineral transformation reactions were controlled by

162 kinetics rate expressions defined by means of thermodynamic constraints and hydrochemical

163 composition (57). We considered the dissimilatory reductive dissolution of ferrihydrite by

164 oxidation of organic matter leading to the release of $\mathrm{Fe}(\mathrm{II})$ and $\mathrm{HCO}_{3}^{-}(2,21,23)$. The kinetic rate

165 of the reaction was expressed as function of the abundance of the electron acceptor (i.e., the 
166 ferrihydrite) with a Monod type rate equation (41, 57, 58). Additional terms allowed us to 167 account for: (i) the decrease in accessibility for reactive surface sites during ferrihydrite 168 dissolution (59), and (ii) the passivation of ferrihydrite via the adsorption of charged species (60169 61).

$$
\mathrm{R}_{\text {ferri }}=-\mathrm{k}_{\text {ferri }}\left(\frac{\left[\mathrm{Fe}(\mathrm{OH})_{3}\right]}{\mathrm{K}_{\mathrm{m}}^{\text {ferri-org }}+\left[\mathrm{Fe}(\mathrm{OH})_{3}\right]}\right)\left(\frac{\mathrm{A}_{\mathrm{Fe}(\mathrm{OH})_{3}}}{\mathrm{~A}_{0, \mathrm{Fe}(\mathrm{OH})_{3}}}\right)\left(\frac{\mathrm{S}_{\text {tot }}-\mathrm{S}_{\text {occupied }}}{\mathrm{S}_{\text {tot }}}\right) \mathrm{L}(\mathrm{t}) \quad\left\{\begin{array}{l}
\mathrm{L}\left(\mathrm{t}<\mathrm{t}_{\mathrm{i}, \text { ferri }}\right)=0 \\
\mathrm{~L}\left(\mathrm{t} \geq \mathrm{t}_{\mathrm{i}, \text { ferri }}\right)=1
\end{array}\right.
$$

170 where $\mathrm{k}_{\text {ferri }}$ is the rate constant, $\mathrm{K}_{\mathrm{m}}^{\text {ferri-org }}$ is the half-saturation constant, $\mathrm{A}_{\mathrm{Fe}(\mathrm{OH})_{3}}$ and $\mathrm{A}_{0, \mathrm{Fe}(\mathrm{OH})_{3}}$ 171 are the total surface areas of ferrihydrite at time $t$ and $t=0$, respectively, $S_{\text {tot }}$ is the total amount of 172 ferrihydrite surface sites, and $S_{\text {occupied }}$ is the amount of ferrihydrite surface sites occupied by $173 \mathrm{Fe}(\mathrm{II})(60)$, phosphate $(61), \operatorname{As}(\mathrm{V})(14,16)$, silicates, and carbonates. As(III) was not included in 174 the surface site passivation term since it rather favors ferrihydrite dissimilatory reduction (14).

175 Quantities in brackets, [ ], represent the molar concentration of the indicated species. $\mathrm{K}_{\mathrm{m}}^{\text {ferri-org }}$ 176 was defined proportional to the amount of Fe(III) crystalline oxide formed during the in-situ 177 experiment, since this can limit ferrihydrite reactivity (23):

$$
\mathrm{K}_{\mathrm{m}}^{\text {ferri-org }}=\mathrm{K}_{\mathrm{m}, 0}^{\text {ferri-org }} \frac{[\mathrm{FeOOH}]}{\left[\mathrm{Fe}(\mathrm{OH})_{3}\right]+[\mathrm{FeOOH}]}
$$

178 where $\mathrm{K}_{\mathrm{m}, 0}^{\text {ferri-org }}$ is a calibrated variable.

$179 \mathrm{~L}(\mathrm{t})$ expresses the inhibition of the reductive dissolution of ferrihydrite for each well over a time 180 period $t_{i}$, ferri, as the dataset indicated a lag phase preceding the decrease in the solid-associated Fe 181 content. The abiotic reduction of ferrihydrite by sulfide was not considered in the model as it was 182 not possible to distinguish its effect from the microbial reductive dissolution of ferrihydrite. The 
183 consumption of organic carbon was simulated according to the reactions and stoichiometry 184 reported in Table 1. Organic carbon was not considered as limiting factor for the reaction 185 kinetics due to its abundance in the flowing groundwater and to its reactivity in the area of the in186 situ experiment (62).

187 The Fe(II)-catalyzed conversion of ferrihydrite into a more crystalline Fe(III) oxide phase 188 (comprising goethite and lepidocrocite) occurs via Ostwald ripening (16, 24, 63-64). The kinetic 189 rate, $\mathrm{R}_{\text {Ostwald }}$ considers the $\mathrm{Fe}(\mathrm{II})$ surface coverage (21, 30, 65-67), the dissolved $\mathrm{Fe}(\mathrm{II})$ 190 concentration $(25-26,68)$, and the effect of chloride, sulfate, and bicarbonate concentrations 191 since these ions have been shown to significantly slow down the crystallization of ferrihydrite 192 (69):

$$
\mathrm{R}_{\text {Ostwald }}=-\left(\mathrm{k}_{1}\left(\frac{\mathrm{S}_{\mathrm{Fe}(\mathrm{II})}}{\mathrm{S}_{\mathrm{tot}}}\right)+\mathrm{k}_{2} \frac{\left[\mathrm{Fe}^{2+}\right]}{\left[\mathrm{Fe}(\mathrm{OH})_{3}\right]}\right)\left(\frac{\left[\mathrm{Fe}(\mathrm{OH})_{3}\right]}{\mathrm{K}_{\mathrm{m}}^{\text {ferri-ost }}+\left[\mathrm{Fe}(\mathrm{OH})_{3}\right]}\right)\left(\frac{1}{\left[\mathrm{Cl}^{-}\right]+\left[\mathrm{SO}_{4}^{2-}\right]+\left[\mathrm{HCO}_{3}^{-}\right]}\right)^{\mathrm{x}}
$$

193 where $\mathrm{k}_{1}$ and $\mathrm{k}_{2}$ are rate constants, $\mathrm{S}_{\mathrm{Fe}(\mathrm{II})}$ is the amount of ferrihydrite surface sites occupied by $194 \mathrm{Fe}(\mathrm{II})$, and $\mathrm{x}$ is a calibrated exponent. The abiotic dissolution of ferrihydrite resulting from 195 electron transfer from aqueous Fe(II) is inhibited when the electrochemical potential of the redox 196 couple $\mathrm{Fe}(\mathrm{II}) / \mathrm{Fe}(\mathrm{III})$ exceeds the absolute energy of the conduction band of ferrihydrite (i.e., $\left.197 \mathrm{E}_{\mathrm{Fe}(\mathrm{OH})_{3}}=-5.00 \mathrm{eV}\right)(25-26,68)$. All produced $\mathrm{Fe}^{3+}$ was turned into a single $\mathrm{Fe}(\mathrm{III})$ crystalline 198 phase. Furthermore, the formation of magnetite was not considered as this mineral was not 199 detected during the in-situ experiments.

200 Siderite and mackinawite were allowed to precipitate as products of the reaction of Fe(II) from 201 the reactive dissolution of ferrihydrite and dissolved carbonate and sulfide species present in the 
202 flowing groundwater. The precipitation of these secondary minerals was controlled by the kinetic 203 rate expressions:

$$
\begin{gathered}
\mathrm{R}_{\text {sid-pptn }}=\mathrm{k}_{\text {sid-pptn }} \max \left(0,\left[1-\frac{\mathrm{K}_{\text {sp(sid) }}}{\mathrm{IAP}_{\text {sid }}}\right]\right) \\
\mathrm{R}_{\text {mack-pptn }}=\mathrm{k}_{\text {mack-pptn }} \max \left(0,\left[1-\frac{\mathrm{K}_{\text {sp(mack })}}{\mathrm{IAP}_{\text {mack }}}\right]\right)
\end{gathered}
$$

204 where $\mathrm{K}_{\mathrm{sp}}$ is the solubility product and IAP is the ion activity product.

205 Arsenic release and sequestration. The change in speciation of arsenic, from As(V) to As(III), 206 occurring when the reduced groundwater contacted the As-loaded ferrihydrite-coated sand, was 207 described as a linear kinetically-controlled mechanisms with a rate coefficient $\mathrm{k}_{\text {As. }}$. Sorption 208 reactions were assumed to be instantaneous and were modeled for ferrihydrite and the secondary 209 Fe(III) oxide using the diffuse double layer (DDL) model (70). Ferrihydrite was defined with a 210 specific surface area of $600 \mathrm{~m}^{2} / \mathrm{g}$ and with weak and strong adsorption sites (i.e., $\mathrm{Hfo}_{\mathrm{w}}$ and $\mathrm{Hfo}_{\mathrm{s}}$, 211 respectively) (70). The secondary Fe(III) oxide was assumed to have the surface complexation 212 properties of goethite and was represented with a specific surface area of $54 \mathrm{~m}^{2} / \mathrm{g}$ and a single 213 type of surface sites (i.e., Goe) (71). The densities of surface sites $\mathrm{Hfo}_{\mathrm{w}}$ and Goe were calibrated 214 within the range $[0.05-0.31] \mathrm{mol} / \mathrm{mol} \mathrm{Fe}(17,72)$ and $[0.011-0.018] \mathrm{mol} / \mathrm{mol} \mathrm{Fe}(71)$, 215 respectively. The density of $\mathrm{Hfo}_{\mathrm{s}}$ sites was set to $0.005 \mathrm{~mol} / \mathrm{mol} \mathrm{Fe} \mathrm{(70).} \mathrm{Since} \mathrm{the} \mathrm{number} \mathrm{of}$ 216 surface sites are stoichiometrically linked to the mol of mineral phases, reductive transformation 217 of the mineral phases lead to a change in sorption capacity. The set of surface reactions for 218 ferrihydrite was taken from the (70) database and amended with arsenic (17, 73), silica (74), 219 carbonates, and ferrous iron (75) surface reactions. Ferrihydrite and goethite surface reactions 
220 included in the model with respective equilibrium constants are listed in Tables SI4 and SI5 of

221 the Supplementary Information. The affinity constants for ferrihydrite were re-optimized through

222 calibration using their $95 \%$ confidence intervals reported in the literature.

223 In addition to complexation onto Fe(III) mineral phases, As reincorporation into the crystalline 224 oxides $(32,76)$ and/or adsorption onto siderite (29) were considered. These mechanisms were 225 described through the uptake of total aqueous As (i.e., considering the relative proportion of $226 \mathrm{As}(\mathrm{III})$ and $\mathrm{As}(\mathrm{V}))$ by a linear sequestration rate stoichiometrically proportional to the amount of 227 produced siderite and secondary Fe(III) oxide defined as:

$$
\mathrm{R}_{\text {As-seq }}=\alpha\left(\mathrm{R}_{\text {sid-pptn }}+\mathrm{R}_{\text {Ostwald }}\right)
$$

228 where $\alpha$ is the molar ratio of As sequestration. We assumed that no significant amount of As was 229 sequestered by mackinawite $(56,77-78)$.

230 Calibration strategy. The modeling framework aimed at describing the reductive mineral 231 transformations and the As release at different spatial locations during the in-situ experiments. 232 We used a common set of parameters between the different spatial locations. Therefore, 233 calibration of the model parameters was performed simultaneously by parallelizing the 234 simulations of the considered observation wells (Figure 1b). The model parameters were 235 calibrated in the MATLAB ${ }^{\circledR}$ environment with an automated procedure minimizing the root 236 mean squared error (RMSE) between simulated and measured solid-associated species (i.e., total 237 As and total $\mathrm{Fe}$ ) throughout the duration of the experiments. Also the secondary mineral 238 composition representative of the samples at the end of the in-situ experiments and determined 239 by Fe K-edge XANES measurements was included in the calibration. Due to the high number of 
240

241

242

243

244

245

246

247

248

249

250

251

252

parameters and the non-linearity of the problem, the heuristic, global-search particle swarm optimization (PSO) method was chosen to minimize the objective function $(41,79)$.

\section{Results and discussion}

Model-based interpretation of the field observations. The comparison between modeling results and field datasets, displayed in Figure 2, was performed in the three observation wells by considering the temporal change in total solid-associated arsenic (Figures 2a-c), the temporal change in total Fe content (Figures $2 \mathrm{~d}-\mathrm{f}$ ), and the amount of iron oxides present in the mineral assemblage at 80 days (Figures $2 \mathrm{~g}-\mathrm{i}$ ).
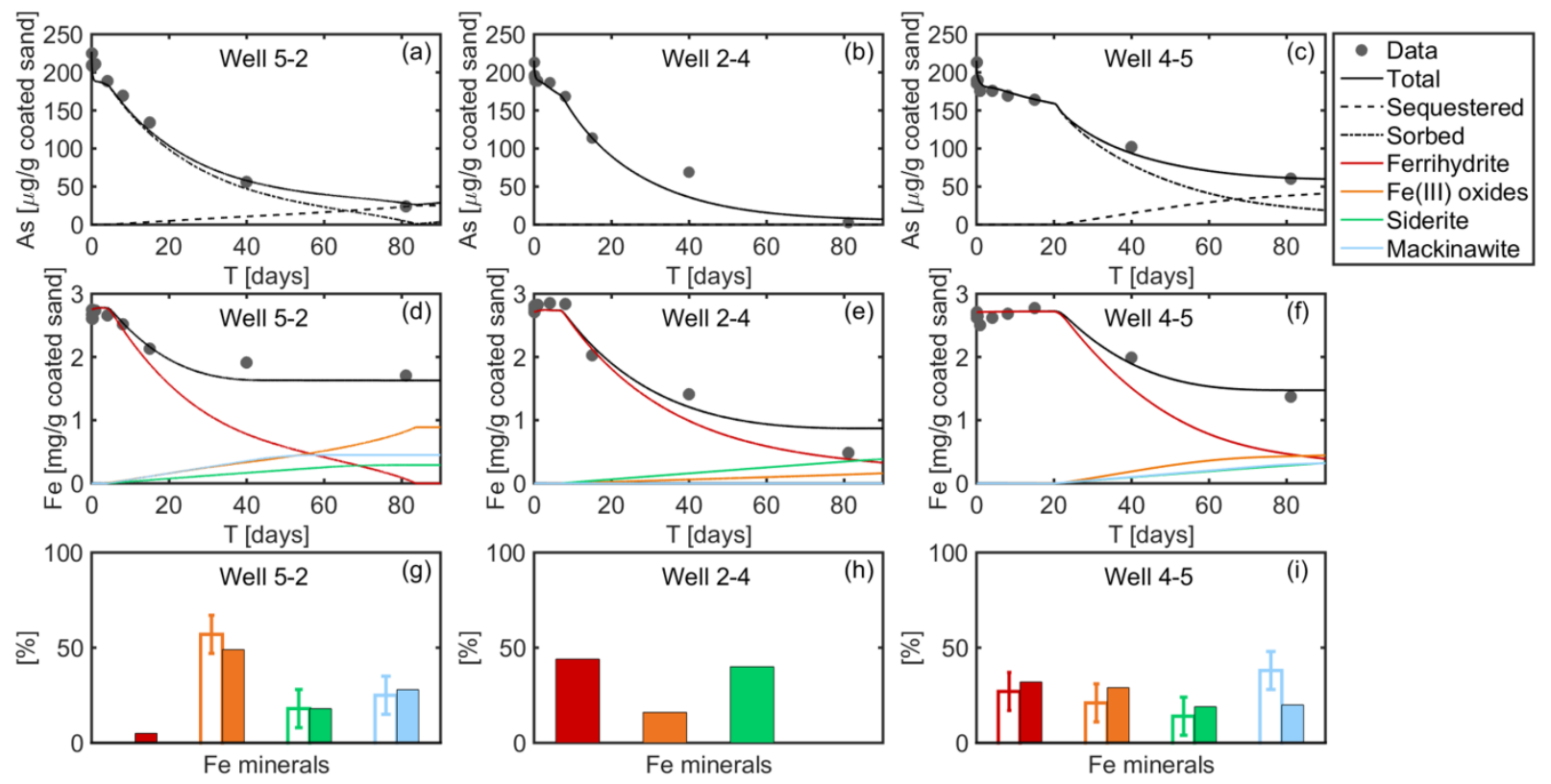

Figure 2. Comparison between experimental data and simulation results. (a)-(c) Dynamic change in total As (note that no sequestered As was predicted in well 2-4); (d)-(f) dynamic change in total Fe and mineral composition; (g)-(i) mineral composition at the end of the experiment: the 
253 full and empty bars represent simulated and experimental results determined by XANES, 254 respectively. The error bars show $10 \%$ uncertainty on quantified mineral fractions for the 255 XANES data available for wells 5-2 and 4-5.

256 The field data suggest that multiple geochemical processes occurring over different time scales 257 control the As mobilization during the in-situ experiments. Indeed, the solid-associated As 258 concentrations exhibit a complex behavior characterized by a significant and rapid release of 259 arsenic at early time followed by a plateau, particularly visible in wells $2-4$ and $4-5$, and a 260 subsequent more gradual release. In contrast, decrease in solid-associated Fe did not start when 261 the reactive mineral was exposed to the groundwater but after an initial delay, which was most 262 pronounced in well 4-5. There is a clear consistency between the patterns of As and Fe contents 263 at the different monitoring locations. In particular, the onset of Fe reductive dissolution 264 corresponds to the time at which the arsenic trend shows a change in its slope and starts the 265 gradual decrease which continues throughout the duration of the experiments. The gradual 266 decrease in solid-associated As and the disintegration of the iron mineral phase appears to 267 proceed congruently in wells $2-4$ and 4-5. In contrast, in well 5-2 the Fe-content reaches steady 268 state after 40 days whereas the solid-associated As continues to decrease over the whole duration 269 of the in-situ experiments. This difference suggests that the As release cannot be linearly 270 associated with the Fe content. Synchrotron Fe K-edge XANES spectra, available for the 271 samples collected in wells 4-5 and 5-2 at the end of the experiments, show that ferrihydrite was 272 converted into Fe(III) oxide (lepidocrocite, goethite), siderite and mackinawite. In particular, 273 conversion into a more crystalline Fe(III) mineral phase was significantly different in the two 274 wells. Specifically, ferrihydrite was completely consumed and a high amount of Fe(III) oxide 
275 was found in well 5-2, whereas high ferrihydrite and a small amount of Fe(III) oxide were 276 observed in 4-5.

277 The existence of multiple surface complexation and mineral transformation mechanisms, which 278 significantly differ among the wells, complicates the interpretation of the processes controlling 279 the As release directly from the experimental datasets. The proposed model allowed us to 280 reproduce the field observations in the three wells with a common set of surface complexation 281 parameters and kinetic parameters for mineral transformation (Tables SI4-6). In particular, the 282 sequential release of As from the solid, occurring at different rates, is captured well by the 283 performed simulations. The modeling results show that the sharp decrease in As at early time is 284 due to desorption as no significant transformation of ferrihydrite was taking place. The duration 285 of the lag phase preceding the reductive microbial dissolution of ferrihydrite (i.e., $\mathrm{t}_{\mathrm{i} \text {, ferri }}$ ) was 286 found to vary among the wells (Table SI6). This difference could suggest spatial heterogeneity of 287 this reaction in the field $(20,80)$. Interestingly, the observed lag phase increases along the 288 selected flow line (i.e. from the mountain towards the flat plain). The model calibrated lag phase 289 appears to scale inversely with the flow velocity and allowed us to reproduce the onset of 290 ferrihydrite disintegration with a similar number $(\sim 300)$ of flushed pore volumes in the three 291 wells. During the reductive dissolution/transformation of ferrihydrite, the solid-associated As 292 concentration becomes function of the As adsorbed onto ferrihydrite and sequestered into the 293 secondary mineral phases. Differences in the calibrated molar ratio of As sequestration $\alpha$ (Table 294 SI6) suggests that this process differs among the wells. In particular, the model predicts that 23, 2950 , and $38 \mu \mathrm{g} \mathrm{As} / \mathrm{g}$ coated sand were sequestered at 80 days in wells 5-2, 2-4, 4-5, respectively 296 even though the amount of crystalline Fe oxides is higher in well 5-2 than 4-5. Furthermore, the 297 model allowed us to reproduce the measured mineral composition for the two wells in which 
298 these measurements were performed. Good agreement was achieved between the observed and 299 simulated amounts of Fe(III) mineral phase, as well as of siderite whereas the model 300 underestimates the amount of mackinawite in well 4-5. The outcomes of the calibrated model are 301 also helpful to visualize the temporal trends of secondary mineral formation and ferrihydrite 302 consumption (Figure $2 \mathrm{~d}-\mathrm{f})$.

303

304 305

Processes controlling arsenic release. The calibrated model was used to distinguish the contributions of different mechanisms controlling the mobilization of arsenic observed during the in-situ experiments. Here, we assess the effects of arsenic change in speciation, sorption, dissolution of ferrihydrite, and arsenic sequestration into secondary Fe oxides. Figure 3 a shows the comparison between simulated solid-associated arsenic for well 4-5 using the calibrated model when individually inhibiting these processes by defining 5 scenarios:

- Scenario A: calibrated model including reduction of adsorbed As(V) to As(III), sorption, reductive dissolution of ferrihydrite, Ostwald ripening, precipitation of ferrous oxides, and arsenic sequestration into the newly formed minerals;

- Scenario B: only sorption processes and reduction of adsorbed As(V) to As(III);

- Scenario C: as Scenario A but without As sequestration into secondary minerals;

- Scenario D: as Scenario A but without the reduction of As(V) to As(III);

- Scenario E: as Scenario A but the change of As(V) to As(III) occurs in the aqueous phase.

Figure $3 \mathrm{~b}$ displays the simulated temporal change of fractional site occupancy occurring to illustrate the sorption competition mechanism taking place during the in-situ experiments. The 

Information (Figure SI1).
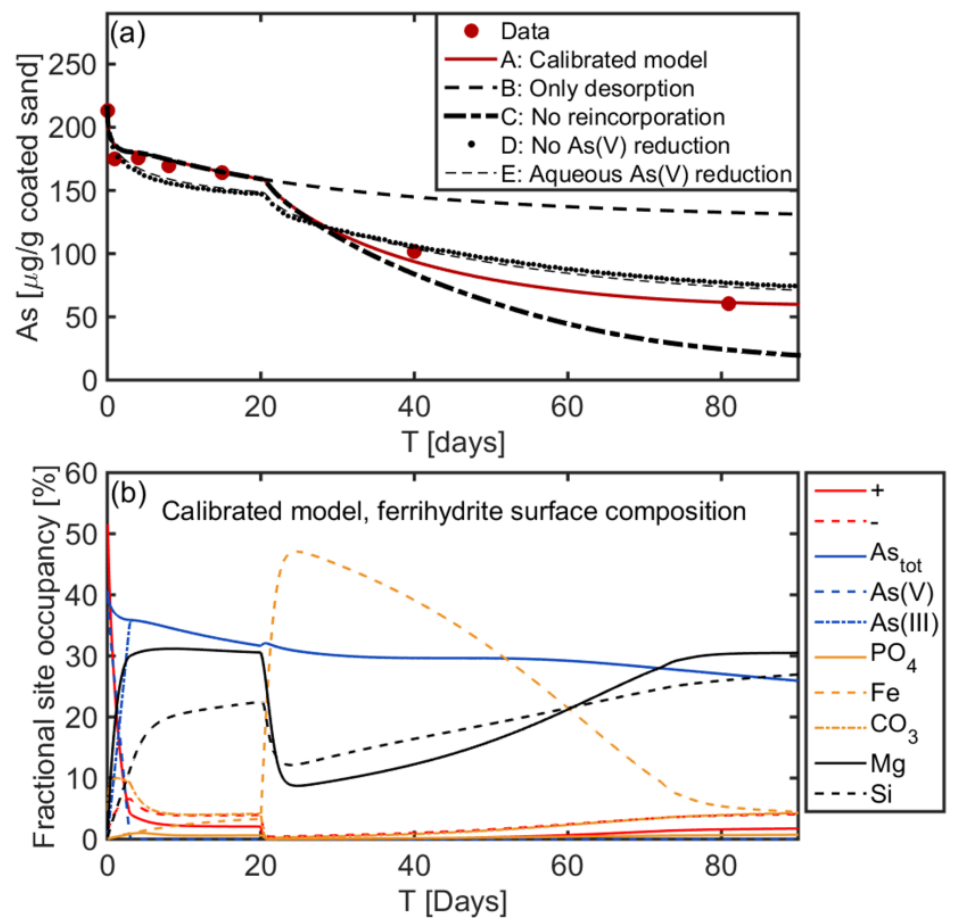

322 Figure 3. (a) Temporal change in total solid-associated arsenic concentration predicted for well

323 4-5 when considering different mechanisms of As sequestration and change of speciation. (b)

324 Simulated temporal change in composition of the weak sites (i.e., Hfo_w) of ferrihydrite in well $325 \quad 4-5$ obtained with the calibrated model.

326 When discarding the iron mineral transformation and only considering As desorption (i.e. 327 Scenario A), the model captures well the first experimental observations but simulates 328 significantly higher As surface concentration after 25 days when ferrihydrite dissolution 329 becomes relevant. This scenario yields a concentration of $133.2 \mu \mathrm{g} \mathrm{As} / \mathrm{g}$ coated sand at the end 330 of the experiments that is more than twice the observed value $60.4 \mu \mathrm{g} \mathrm{As} / \mathrm{g}$ coated sand (Figure 331 3a). This difference shows that the As release from ferrihydrite surface is primarily determined 
332 by the decrease in available sorption sites induced by the disintegration of ferrihydrite whereas

333 sorption competition is of lower importance when reductive dissolution takes place in agreement

334 with the observations of Root et al. (9) on artificially deposited ferrihydrite-rich sediments of the

335 North Haiwee Reservoir (Olancha, CA, USA). Conversely, the model scenario that does not

336 include uptake of arsenic into newly formed minerals predicts higher release of arsenic and, thus,

337 lower As concentration at the end of the experiments (i.e., $24.2 \mu \mathrm{g} \mathrm{As} / \mathrm{g}$ coated sand at 80 days).

338 These simulation results underpin the importance of As sequestration into secondary minerals for

339 the observed behavior at the field site.

340 Direct microbially-mediated reduction of aqueous and/or adsorbed $\mathrm{As}(\mathrm{V})$ has been extensively

341 observed during transition from aerobic to anaerobic conditions (30-31). However, the sequential

342 order in which the biotic reduction of $\mathrm{Fe}(\mathrm{III})$ oxide minerals and $\mathrm{As}(\mathrm{V})$ occur has been debated

$343(14,30,81-83)$. Furthermore, it remains unclear whether bacteria can directly transform the

$344 \operatorname{As}(\mathrm{V})$ into $\operatorname{As}(\mathrm{III})$ on the surface or initially requires the desorption of $\mathrm{As}(\mathrm{V})$. Here, the

345 speciation change of surface-associated $\mathrm{As}(\mathrm{V})$ led to the best agreement with the field dataset. In

346 particular, this mechanism is predicted to limit the release of As from ferrihydrite as a stronger

347 initial As release that is predicted when reduction of surface $\mathrm{As}(\mathrm{V})$ is not considered (Scenarios

$348 \mathrm{D}$ and $\mathrm{E}$ in Figure 3a). When analyzing the simulated temporal change in surface composition

349 (Figure 3b), the adsorbed $\mathrm{As}(\mathrm{V})$ becomes As(III) at early times of the in-situ experiments

350 preceding the reductive dissolution of ferrihydrite (e.g., 7 days in well 4-5).

351 The solid-associated As at the end of the experiment days was predicted as As(III) whereas the

352 speciation determined by K-edge XANES measurements indicated $\operatorname{As}(\mathrm{V})$ as the dominant

353 species (Table SI3). This discrepancy may result from the oxidation of As(III) via interaction 
354 and/or sequestration into the formed crystalline iron phases as observed by Amstaetter et al. (76).

355 Indeed, the model indicates that the main part of the solid-associated As (i.e., $80 \%$ and $62 \%$ in

356 wells 5-2 and 4-5, respectively) is sequestered by the secondary iron oxides at the end of the in-

357 situ experiments.

358 At the beginning of the in-situ experiment, a significant part of the As(V) rapidly desorbs (i.e., 35949 to $35 \%$ surface sites occupancy; Figure 3b). A sensitivity analysis assessing the effect of the 360 aqueous species on the surface composition of ferrihydrite indicates that this desorption is 361 induced by the rapid drop in surface charge primarily due to the re-equilibration of the 362 ferrihydrite surface with the groundwater and, to a lower extent, to the competitive sorption 363 effects of dissolved bicarbonate and silica (see Supplementary Information, Figure SI4). Due to 364 the local hydrochemical conditions and the high As(III) concentrations in the groundwater, none 365 of the aqueous species seems able to substantially compete for As(III) sorption sites as shown by 366 the steady As(III) fractional site occupancy (Figure 3b) leading to a plateau regime in the As 367 surface concentration until As(III) mobilization is triggered by the disintegration of ferrihydrite 368 (Figure 3a). In particular, the As(III) surface site occupancy remains steady at the onset of 369 microbial dissolution of ferrihydrite (i.e., 20 days) characterized by an abrupt change in surface 370 composition due to the strong adsorption of $\mathrm{Fe}(\mathrm{II})$ concomitant to a sharp desorption in $\mathrm{Mg}$ and 371 Si. Similar behavior of As adsorbed onto ferrihydrite is predicted in the other wells even though 372 the sequestration of As into secondary mineral phases spatially differ (Supporting Information, 373 Figure SI1 and Table SI6).

374 Reductive transformation of ferrihydrite. The reductive transformation of ferrihydrite 375 significantly controls the As release through the dissolution of the solid phase. This leads to a 
376 reduction of sorption sites and to the formation of new mineral phases that can potentially

377 sequester arsenic. The model allowed us to assess the relative contribution of the reductive

378 dissolution, $\mathrm{Fe}(\mathrm{II})$-catalyzed transformation, and precipitation of $\mathrm{Fe}(\mathrm{II})$-mineral phases on the

379 change in the total Fe content and in the composition of the mineral assemblage. Figure 4

380 displays the simulation results obtained when considering individually these iron mineral

381 transformation mechanisms through the definition of four different modeling scenarios:

382 - Scenario 1: calibrated model (same as Scenario A above);

383 - Scenario 2: only reductive dissolution of ferrihydrite with no further Fe(II) reactions (i.e., 384 no Ostwald ripening and no Fe(II) precipitation with carbonate and sulfide);

385 - Scenario 3: as Scenario 2 but including Fe(II) precipitation with carbonate and sulfide;

386 - Scenario 4: Fe(II) allowed to react with ferrihydrite through Ostwald ripening but without 387 reductive dissolution. 

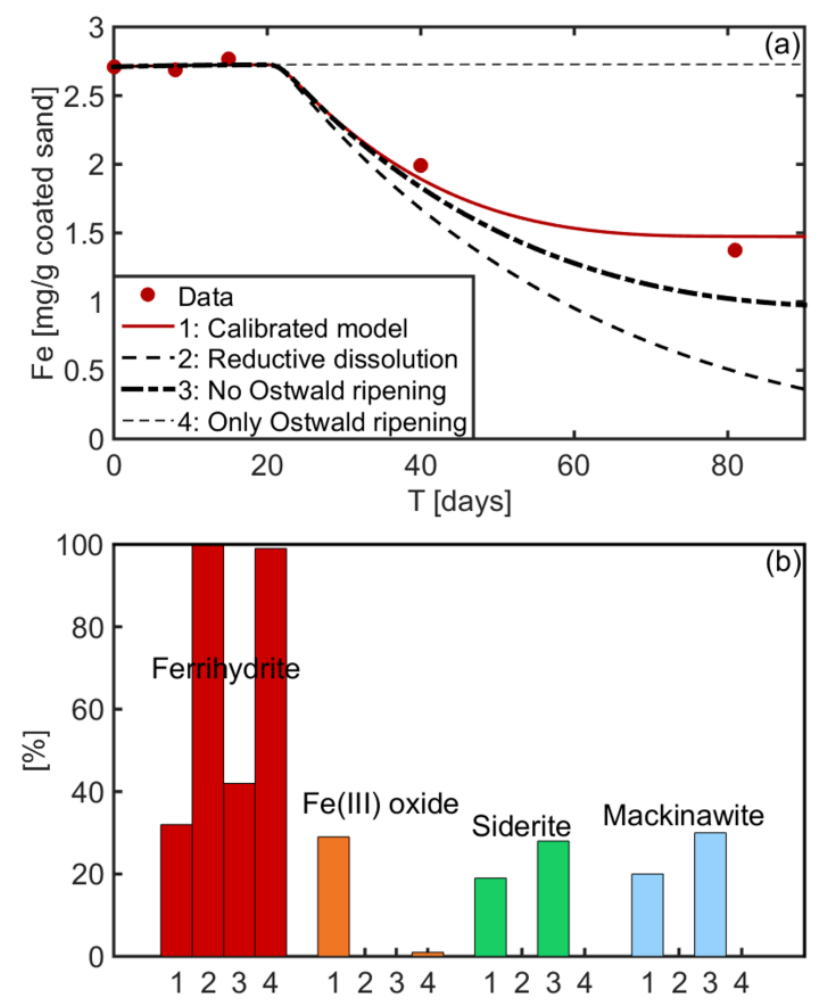

389 Figure 4. (a) Temporal change in total Fe content assessed through the different model scenarios;

390 (b) composition of the mineral assemblage at 80 days predicted for well 4-5 using the model and 391 considering the contributions of the different transformation mechanisms studied in Scenario 1-4.

392 Figure 4a shows that the observed pattern of Fe content measured in well 4-5 is captured well by 393 the calibrated model (Scenario 1). When only defining the reductive dissolution of ferrihydrite 394 (Scenario 2) the Fe-content is significantly underestimated (e.g., $0.49 \mathrm{mg} \mathrm{Fe} / \mathrm{g}$ coated sand 395 compared to the experimental observation of $1.37 \mathrm{mg} \mathrm{Fe} / \mathrm{g}$ coated sand at 80 days). The 396 formation of ferrous iron minerals limits the decrease in solid-associated Fe and improves the 397 agreement with the field data as illustrated by Scenario 3 (e.g., $1.01 \mathrm{mg} \mathrm{Fe} / \mathrm{g}$ coated sand at 80 398 days). However, this scenario does not include Ostwald ripening and results in a slight 399 underestimation of the Fe content. Finally, Scenario 4 that only considers the effect of Ostwald 400 ripening does not capture the observed behavior. This scenario predicts a constant Fe content, 
401 and only minimal conversion of ferrihydrite into Fe(III) oxide compared to Scenario 1. These 402 results suggest that, under the investigated field conditions, the Fe(II) groundwater 403 concentrations are not sufficient to promote significant recrystallization of ferrihydrite and that 404 the reductive dissolution of ferrihydrite is a prerequisite to generate the local $\mathrm{Fe}(\mathrm{II})$ 405 concentrations necessary to substantially convert ferrihydrite into Fe crystalline phases. In 406 particular, the comparison between Scenario 1 and Scenario 3 shows that Ostwald ripening 407 improves the agreement with the experimental data, through the preservation of solid-associated $408 \mathrm{Fe}$, when it is considered together with the reductive dissolution of ferrihydrite and the formation 409 of $\mathrm{Fe}(\mathrm{II})$ secondary minerals.

Fe(II)-induced mineralization pathways. The type of secondary minerals, as well as the extent

411 and the kinetics of the conversion of ferrihydrite into more crystalline $\mathrm{Fe}(\mathrm{III})$ oxides, are 412 primarily controlled by the supply rate and the magnitude of the aqueous Fe(II) concentration (21, 413 84). However, significant differences in the crystallization of ferrihydrite can be observed 414 between the wells despite similar surface and aqueous Fe(II) concentrations simulated upon 415 ferrihydrite dissolution (Figure SI3). This suggests that other mechanisms influence the Fe(II)416 induced transformation of ferrihydrite and ultimately the As mobility. Adsorbed trace elements 417 and/or the presence of major ions are known to determine the choice of the Fe(II)-induced 418 mineralization pathway from ferrihydrite $(69,85)$. In particular, the lower crystallization of 419 ferrihydrite predicted in well 2-4 (Figure 2) might be ascribed to the relatively higher chloride, 420 sulfate and bicarbonate concentrations in that well directly considered in the kinetic rate 421 expression controlling the Ostwald ripening reaction (Equation 2, Table SI2), which is in 422 agreement with previous studies (69). Furthermore, the presence of magnetite that forms through 423 topotactic transformation during $\mathrm{Fe}(\mathrm{II})$-induced crystallization of ferrihydrite was not observed 
424 during the in-situ experiments. Magnetite is typically observed in presence of high ferrous iron 425 concentrations that impede the release of $\mathrm{Fe}(\mathrm{II})$ from the mineral and result in a mix $\mathrm{Fe}(\mathrm{II})-\mathrm{Fe}$ (III) 426 solid $(23-24,65,21,66,69)$. Despite relatively low dissolved Fe(II) concentration simulated by 427 the model (always less than $1 \mathrm{mM}$, Figure SI3), the ratio between ferrous iron and ferrihydrite 428 concentrations at which formation of magnetite is typically observed (i.e., $1 \mathrm{mmol} \mathrm{Fe(II)/g} \mathrm{Hfo}$ 429 (39)) was exceeded upon reductive dissolution of ferrihydrite (i.e., [2 - 10] mmol Fe(II)/g Hfo). 430 However, magnetite was not observed during the in-situ experiments. This result can be 431 explained by the relatively low groundwater concentration of $\mathrm{Fe}(\mathrm{II})$ that was maintained during 432 the initial phase preceding the onset of ferrihydrite reduction. Over this initial period, 433 accumulation of small amounts of lepidocrocite and/or goethite favored by the action of Fe(II) on 434 ferrihydrite could have led to surface site passivation preventing the formation of magnetite 435 despite the high concentration of $\mathrm{Fe}(\mathrm{II})$ occurring upon ferrihydrite reductive dissolution. A 436 similar effect has been observed in controlled laboratory experiments (64).

437 Implications. The reductive dissolution of poorly crystalline iron oxides has been recognized as 438 one of the predominant pathways leading to As contamination of groundwater $(7,20)$. However, 439 the complex interplay of geochemical processes in natural groundwater systems hampers a 440 detailed description of the mechanisms controlling the fate and evolution of mineral phases and 441 As release from the sole analysis of water chemistry and mineral characterization data. This 442 study has highlighted the importance of multiple mechanisms (i.e., surface complexation, 443 reductive dissolution, formation of secondary iron minerals and arsenic sequestration into the 444 newly formed minerals), occurring at different time scales and with significant spatial variability, 445 when groundwater contacts ferrihydrite and triggers the release of arsenic. The model-based 446 interpretation of the in-situ experiments was instrumental to disentangle the roles of the different 
447 geochemical processes on the evolution of the mineral assemblage and arsenic in the flow448 through system. While part of the arsenic rapidly desorbed from ferrihydrite, most of the 449 mobilization of solid-associated arsenic was controlled by the reductive dissolution of the 450 primary mineral and sequestration (i.e., sorption and reincorporation) into secondary iron oxides 451 in agreement with previous laboratory studies (30). Formation of these more crystalline phases 452 was found to be induced by the $\mathrm{Fe}(\mathrm{II})$ generated from the disintegration of ferrihydrite triggering 453 further mineral crystallization. The model highlights important implications of different 454 geochemical mechanisms on the evolution of solid-associated iron and, thus, on the release of 455 arsenic. The kinetics of the transformation of ferrihydrite was particularly influenced by the 456 dissolved groundwater species (e.g., charged solutes) through chemical and electrostatic 457 interactions, and by mineral assemblage composition and transformation. The absence of 458 magnetite formation during the in-situ experiment, despite the high level of generated Fe(II), 459 contrasts with previous laboratory studies which extensively reported magnetite formation upon 460 reductive dissolution of ferrihydrite. This calls for further investigation on the mechanisms 461 controlling the mineralization pathway during Fe(II)-catalyzed transformation of ferrihydrite. 462 The outcomes of this modeling study emphasize the importance of detailed experimental 463 observations able to capture the temporal dynamics and the spatial variability of geochemical 464 controls on arsenic mobilization. The determination of solid-associated arsenic and iron 465 concentrations, together with the microscopic and spectroscopic characterization of primary and 466 secondary minerals and the chemistry of the groundwater, contributed to underpin the model467 based interpretation.

468 The performed model-based analysis was carried out using a one-dimensional flow-through 469 approach at specific spatial locations where experimental observations were available. The 
470 understanding gained on the temporal dynamics and kinetic parameters for the different

471 geochemical processes could be exported and tested in multidimensional flow-through domains,

472 which have additional degrees of freedom whose effects cannot be easily extrapolated from 1-D

473 setups (86-87). The integration of the knowledge on arsenic release and iron transformation in

474 multidimensional reactive transport models of groundwater flow systems will allow the joint

475 consideration of the geochemical complexity, highlighted in this investigation, with the physical

476 and chemical heterogeneity of groundwater flow system (88-91). This will contribute to improve

477 our capability to describe and predict the release, transport, and fate of arsenic in complex,

478 heterogeneous aquifer systems. Such approach based on mechanistic description of physical and

479 biogeochemical processes also represents a promising design tool for remediation strategies

480 based on amendments injection and enhanced reactive mineral transformation.

481

$482 \quad$ Associated content

\section{Supporting Information}

484 Field data: wells technical information, measured groundwater aqueous composition used as 485 input parameters in the reactive transport model, measured time series of total Fe and As, the 486 mineral composition and solid-associated arsenic speciation measured at 80 days. Tables 487 summarizing literature and optimized values of the affinity constants used in the surface 488 complexation models as well as the optimized model parameters. Model results showing the 489 change in surface composition and aqueous composition simulated in other wells. Results of a 490 sensitivity analysis performed to assess the effects of hydrochemical composition on the surface 491 composition of ferrihydrite. 


\section{Acknowledgments}

493 This work was funded by the Sino-Danish Center for Education and Research (SDC) with a PhD

494 scholarship granted to L.S. M.R. also acknowledges the support of the Villum Block Fellowship

495 (Villum Fonden, Denmark). G.H. and D.Z. are grateful for the support of the National Natural

496 Science Foundation of China (grant Nos. 41825017 and 41672225) and the Fundamental

497 Research Funds for the Central Universities (grant No. 2652017165). 
(1) Smedley, P. L.; Kinniburgh, D. G. A review of the source, behaviour and distribution of arsenic in natural waters. Appl. Geochem. 2002, 17(5), 517-568; DOI: 10.1016/S08832927(02)00018-5.

501

502

(2) Appelo, C.; Postma, D. Geochemistry, groundwater and pollution, $2^{\text {nd }}$, ed.; London: CRC Press, 2005.

(3) Bretzler, A.; Stolze, L.; Nikiema, J.; Lalanne, F.; Ghadiri, E.; Brennwald, M. S.; Rolle, M.; Schirmer, M. Hydrogeochemical and multi-tracer investigations of arsenic-affected aquifers in semi-arid West Africa. Geosci. Front. 2018, In Press, DOI:

506

507 10.1016/j.gsf.2018.06.004.

(4) Fendorf, S.; Michael, H. A.; van Geen, A. Spatial and temporal variations of groundwater arsenic in South and Southeast Asia. Science 2010, 328(5982), 1123-1127;

(5) Berg, M.;Tran, H. C.; Nguyen, T. C.; Pham, H. V.; Schertenleib, R.; Giger, W. Arsenic

(6) Harvey, C. F.; Swartz, C. H.; Badruzzaman, A. B. M.; Keon-Blute, N.; Yu, W.; Ali, M.

(8) Mladenov, N.; Zheng, Y.; Miller, M. P.; Nemergut, D. R.; Legg, T.; Simone, B.; A.; Jay, J.; Beckie, R.; Niedan, V.; Brabander, D.; Oates, P. M.; Ashfaque, K. N.; Islam, S.; Hemond, H. F.; Ahmed, M. F. Arsenic mobility and groundwater extraction in Bangladesh. Science 2002, 298(5598), 1602-1606; DOI: 10.1126/science.1076978.

(7) Meharg, A. A.; Scrimgeour, C.; Hossain, S. A.; Fuller, K.; Cruickshank, K.; Williams, P. N.; Kinniburgh, D. G. Codeposition of organic carbon and arsenic in Bengal delta aquifers. Environ. Sci. Technol. 2006, 40, 4928-4935; DOI: 10.1021/es060722b.

(10) Jessen, S.; Postma, D.; Larsen, F.; Nhan, P. Q.; Hoa, L. Q.; Trang, P. T. K.; Long, T. V.; 
mobility: Results of a forced gradient experiment in a Red River flood plain aquifer, Vietnam. Geochim. Cosmochim. Acta 2012, 98, 186-201; DOI: 10.1016/j.gca.2012.07.014.

(11) Wang, L.; Giammar, D. E. Effects of $\mathrm{pH}$, dossolved oxygen, and aqueous ferrous iron on the adsorption of arsenic to lepidocrocite. J. Colloid Interface Sci. 2015, 448, 331 338; DOI: 10.1016/j.jcis.2015.02.047.

(12) Postma, D.; Trang, P.T.K.; Sø, H.U.; Hoan, H.V.; Lan, V.M.; Thai, N.T.; Larsen, F.; Viet, P.H.; Jakobsen, R. A model for the evolution in water chemistry of an arsenic contaminated aquifer over the last 6000 years, Red River floodplain, Vietnam. Geochim. Cosmochim. Acta. 2016, 195, 277-292; DOI: .1016/j.gca.2016.09.014.

(13) Sø, H. U.; Postma, D.; Hoang, V. H.; Mai, L. V.; Kim, T. P. T.; Hung, V. P.; Jakobsen, $\mathrm{R}$. Arsenite adsorption controlled by the iron oxide content of Holocene Red River aquifer sediment. Geochim. Cosmochim. Acta. 2018, 239, 61-73; DOI: 10.1016/j.gca.2018.07.026.

(14) Campbell, K. M.; Malasarn, D.; Saltikov, C. W.; Newman, D. K.; Hering, J. G. Simultaneous microbial reduction of iron(III) and arsenic(V) in suspensions of hydrous ferric oxide. Environ. Sci. Technol. 2006, 40(19), 5950-5955; DOI: 10.1021/es0600476.

(15) Tufano, K. J.; Reyes, C.; Saltikov, C.; Fendorf, S. Reductive processes controlling arsenic retention: revealing the relative importance of iron and arsenic retention. Environ. Sci. Technol. 2008, 42, 8283-8289; DOI: 10.1021/es801059s.

(16) Tufano, K. J.; Fendorf, S. Confounding impacts of iron reduction on arsenic retention. Environ. Sci. Technol. 2008, 42(13), 4777-4783; DOI: 10.1021/es702625e.

(17) Dixit, S.; Hering, J. G. Comparison of Arsenic(V) and Arsenic(III) sorption onto iron oxide minerals: implications for arsenic mobility. Environ. Sci. Technol. 2003, 37(18), 4182-4188; DOI: 10.1021/es030309t.

(18) Akai, J.; Izumi, K.; Fukuhara, H.; Masuda, H.; Nakano, S.; Yoshimura, T.; Ohfuji, H.; Md Anawar, H.; Akai, K. Mineralogical and geomicrobiological investigations on groundwater arsenic enrichment in Bengladesh. Appl. Geochem. 2004, 19(2), 215-230; DOI: 10.1016/j.apgeochem.2003.09.008.

(19) Sun, J.; Mailloux, B. J.; Chillrud, S. N.; van Geen, A.; Thompson, A.; Bostick, B. C. Simultaneously quantifying ferrihydrite and goethite in natural sediments using the method of standard additions with X-ray absorption spectroscopy. Chem. Geol 2018a, 476, 248-259; DOI: 10.1016/j.chemgeo.2017.11.021. 
(20) Stuckey, J. W.; Schaefer, M. V.; Benner, S. G.; Fendorf, S. Reactivity and speciation of mineral-associated arsenic in seasonal and permanent wetlands of the Mekong Delta. Geochim. Cosmochim. Acta 2015a, 171, 143-155; DOI: 10.1016/j.gca.2015.09.002.

(21) Zachara, J. M.; Kukkadapu, R. K.; Frederickson, J. K.; Gorby, Y. A.; Smith, S. C. Biomineralization of poorly crystalline $\mathrm{Fe}(\mathrm{III})$ oxides by dissimilatory metal reducing bacteria (DMRB). Geomicrobiol. J. 2002, 19, 179-207; DOI: 10.1080/01490450252864271.

(22) Weber, K. A.; Achenbach, L. A.; Coates, J. D. Microorganisms pumping iron: anaerobic microbial iron oxidation and reduction. Nat. Rev. Microbiol. 2006, 4, 752-764; DOI: $10.1038 /$ nrmicro1490.

(23) Benner, S; Hansel, C. M.; Wielinga, B. W.; Barber, T. M.; Fendorf, S. Reductive dissolution and biomineralization of iron hydroxide under dynamic flow conditions. Environ. Sci. Technol. 2002, 36(8), 1705-1711; DOI: 10.1021/es0156441.

(24) Pedersen, H. D.; Postma, D.; Jakobsen, R.; Larsen, O. Fast transformation of iron oxyhydroxides by the catalytic action of aqueous Fe(II). Geochim. Cosmochim. Acta 2005, 69(16), 3967-3977; DOI: 10.1016/j.gca.2005.03.016.

(25) Yang, L.; Steefel, C. I.; Marcus, M. A.; Bargar, J. R. Kinetics of Fe(II)-catalyzed transformation of 6-line ferrihydrite under anaerobic conditions. Environ. Sci. Technol. 2010, 44(14), 5469-5475; DOI: 10.1021/es1007565.

(26) Boland, D. D.; Collins, R. N.; Miller, C. J.; Glover, C. J.; Waite, T. D. Effect of solution and solid-phase conditions on the $\mathrm{Fe}(\mathrm{II})$-accelerated transformation of ferrihydrite to lepidocrocite and goethite. Environ. Sci. Technol. 2014, 48(10), 5477-5485, DOI: $10.1021 / \mathrm{es} 4043275$.

(27) Kocar, B. D.; Fendorf, S. Thermodynamic constraints on reductive reactions influencing the biogeochemistry of arsenic in soils and sediments. Environ. Sci. Technol. 2009, 43, 4871-4877; DOI: 10.1021/es8035384.

(28) Ford, R. Rates of hydrous ferric oxide crystallization and the influence on coprecipitated arsenate. Environ. Sci. Technol. 2002, 36(11), 2459-2463; DOI: 10.1021/es015768d.

(29) Islam, F. S.; Pederick, R. L.; Gault, A. G.; Adams, L. K.; Polya, D. A.; Charnock, J. M.; Lloyd, J. R. Interactions between the Fe(III)-reducing bacterium Geobacter sulfurreducens and arsenate, and capture of the metalloid by biogenic Fe(II). Appl. Environ. Microbiol. 2005, 71(12), 8642-8648; DOI: 10.1128/AEM.71.12.86428648.2005. 
(30) Herbel, M. J.; Fendorf, S. Biogeochemical processes controlling the speciation and transport of arsenic within iron coated sands. Chem. Geol. 2006, 228(1-3), 16-32; DOI: 10.1016/j.chemgeo.2005.11.016.

(31) Kocar, B. D.; Herbel, M. J.; Tufano, K. J.; Fendorf, S. Contrasting effects of dissimilatory iron (III) and arsenic (V) reduction on arsenic retention and transport. Environ. Sci. Technol. 2006, 40(21), 6715-6721; DOI: 10.1021/es061540k.

(32) Pedersen, H. D.; Postma, D.; Jakobsen, R. Release of arsenic associated with the reduction and transformation of iron oxides. Geochim. Cosmochim. Acta 2006, 70, 4116-4129; DOI: 10.1016/j.gca.2006.06.1370.

(33) Neidhardt, H.; Berner, Z. A.; Freikowski, D.; Biswas, A.; Majumder, S.; Winter, J.; Gallert, C.; Chatterjee, D.; Norra, S. Organic carbon induced mobilization of iron and manganese in a West Bengal aquifer and the muted response of groundwater arsenic concentrations. Chem. Geol. 2014, 367, 51-62; DOI: 10.1016/j.chemgeo.2013.12.021.

(34) Rawson, J.; Siade, A.; Sun, J.; Neidhardt, H.; Berg, M.; Prommer, H. Quantifying reactive transport processes governing arsenic mobility after injection of reactive organic carbon into a Bengal Delta aquifer. Environ. Sci. Technol. 2017, 51(15), 84718480; DOI: 10.1021/acs.est.7b02097.

(35) Nielsen, S.; Kjeldsen, P.; Bruun Hansen, H.; Jakobsen, R. Transformation of natural ferrihydrite aged in situ in $\mathrm{As}, \mathrm{Cr}$ and $\mathrm{Cu}$ contaminated soil studied by reduction kinetics. Appl. Geochem. 2014, 51, 293-302; DOI: 10.1016/j.apgeochem.2014.10.014.

(36) Stuckey, J. W.; Schaefer, M. V.; Kocar, B. D.; Benner, S. G.; Fendorf, S. Arsenic release metabolically limited to permanently water-saturated soil in Mekong Delta. Nat. Geosci. 2015b, 9, 70-78; DOI: 10.1038/ngeo2589.

(37) Zhang, Di; Guo, H.; Xiu, W.; Ni, P.; Zheng, H.; Wei, C. In-situ mobilization and transformation of iron oxides-adsorbed arsenate in natural groundwater. J. Hazard. Mater. 2017, 321, 228-237; DOI: 10.1016/j.jhazmat.2016.09.021.

(38) Neidhardt, H.; Winkel, L. H. E.; Kaegi, R.; Stengel, C.; Trang, P. T. K.; Lan, V. M.; Viet, P. H.; Berg, M. Insights into arsenic retention dynamics of Pleistocene aquifer sediments by in situ sorption experiments. Water Res. 2018, 129, 123-132; DOI: 10.1016/j.watres.2017.11.018.

(39) Tufano, K. J.; Benner, S. G.; Mayer, K. U.; Marcus, M. A.; Nico, P. S.; Fendorf, S. Aggregate-scale heterogeneity in iron (hydr)oxide reductive transformations. Vadose Zone J. 2009, 8(4), 1004-1012; DOI: 10.2136/vzj2008.0090. 
(40) Sharma, P.; Rolle, M.; Kocar, B.; Fendorf, S.; Kappler, A. Influence of natural organic matter on As transport and retention. Environ. Sci. Technol. 2011, 45, 546-553; DOI: 10.1021/es1026008

(41) Rawson, J.; Prommer, H.; Siade, A.; Carr, J.; Berg, M.; Davis, J. A.; Fendorf, S. Numerical modeling of arsenic mobility during reductive iron-mineral transformations. Environ. Sci. Technol. 2016, 50(5), 2459-2467; DOI: 10.1021/acs.est.5b05956.

(42) Sun, J.; Prommer, H.; Siade, A.J.; Chillrud, S. N.; Mailloux, B. J.; Bostick, B. C. Model-based analysis of arsenic immobilization via iron mineral transformation under advective flows. Environ. Sci. Technol. 2018b, 52(16), 9243-9253; DOI: 10.1021/acs.est.8b01762.

(43) Postma, D.; Larsen, F.; Hue, N.T.M.; Duc, M.T.; Viet, P.H.; Nhan, P.Q.; Jessen, S. Arsenic in groundwater of the Red River floodplain, Vietnam: Controlling geochemical processes and reactive transport modeling. Geochim. Cosmochim. Acta. 2007, 71, 50545071; DOI: 10.1016/j.gca.2007.08.020.

(44) Kocar, B.D.; Polizotto, M.L.; Benner, S.G.; Ying, S.C.; Ung, M.; Ouch, K.; Samreth, S.; Suy, B.; Phan, K.; Sampson, M.; Fendorf, S. Integrated biogeochemical and hydrologic processes driving arsenic release from shallow sediments to groundwaters of the Mekong delta. Appl. Geochem. 2008, 23, 3059-3071; DOI: 10.1016/j.apgeochem.2008.06.026

(45) Stolze, L.; Zhang, D.; Guo, H.; Rolle, M. Surface complexation modeling of arsenic mobilization from goethite: Interpretation of an in-situ experiment. Geochim. Cosmochim. Acta 2019, 248, 274-288; DOI: 10.1016/j.gca.2019.01.008.

(46) Schwertmann, U.; Cornell, R.M. Iron oxides in the laboratory - Preparation and characterization; Wiley-VCH: Weinheim, 2000.

(47) Link, D.D.; Walter, P.J.; Kingston, H.M. Development and validation of the new EPA microwave-assisted leach method 3051A. Environ. Sci. Technol. 1998, 32(22), 36283632; DOI: 10.1021/es980559n

(48) Parkhurst, D. L.; Appelo, C. A. J., 2013. Description of input and examples for PHREEQC version 3 - A computer program for speciation, batch-reaction, onedimensional transport, and inverse geochemical calculations. In: U.S. Geological Survey Techniques amd Methods, book 6, chap. A43, p. 497.

(49) Haberer, C.; Muniruzzaman, M.; Grathwohl, P; Rolle, M. Diffuse-dispersive and reactive fronts in porous media. Vadose Zone J. 2015, 14(5), 1-14, DOI: 10.2136/vzj2014.07.0091. 
(50) Rolle, M.; Sprocati, R.; Masi, M.; Jin, B.; Muniruzzaman, M. Nernst-Planck based description of transport, coulombic interactions and geochemical reactions in porous media: modeling approach and benchmark experiments. Water Resour. Res. 2018, 54(4), 3176-3195; DOI: 10.1002/2017WR022344.

(51) Charlton, S. R.; Parkhurst, D. L. Modules based on the geochemical model PHREEQC for use in scripting and programming languages. Comput. Geosci. 2011, 37, 1653-1663.

(52) Muniruzzaman, M.; Rolle, M. Modeling multicomponent ionic transport in groundwater with IPhreeqc coupling: Electrostatic interactions and geochemical reactions in homogeneous and heterogeneous domains. Adv. Water Resour. 2016, 98, 1-15; DOI: 10.1016/j.advwatres.2016.10.013.

(53) Schecher, W. D.; McAvoy, D. C. MINEQL+, V. 4.5, Users Manual, Hallowell, ME, 1998.

(54) Langmuir, D. The Gibbs free energies of substances in the system $\mathrm{Fe}-\mathrm{O}_{2}-\mathrm{H}_{2} \mathrm{O}-\mathrm{CO}_{2}$ at 25C. In: Geological Survey research; USGS Prof. pap. 650-B; U.S. Gov. Print. Office, Washington, DC. 1969; pp B180-B183.

(55) Nordstrom, D. K.; Plummer, L. N.; Langmuir, D.; Busenberg, E.; May, H. M.; Jones, B. F.; Parkhurst, D. L. Revised chemical equilibrium data for major water-mineral reactions and their limitations. In: Chemical Modeling of Aqueous Systems II, Bassett, R.L., Melchior, D., Eds.; American Chemical Society Symposium Series 416, 1990, pp 398-413.

(56) Burton, E. D.; Johnston, S. G.; Bush, R. T. Microbial sulfidogenesis in ferrihydrite-rich environments : Effects on iron mineralogy and arsenic mobility. Geochim. Cosmochim. Acta 2011, 75(11), 3072-3087; DOI: 10.1016/j.gca.2011.03.001.

(57) Van Capellen, P; Gaillard, J.-F. Biogeochemical dynamics in aquatic sediments. In: Reactive transport in porous media. Lichtner P. C., Steefel C. I., Oelkers E. H. Eds.; The Mineralogical Society of America, Washington DC 1996; 335-376.

(58) Pallud, C.; Kausch, M.; Fendorf, S.; Meile, C. Spatial patterns and modeling of reductive ferrihydrite transformation observed in artifical soil aggregates. Environ. Sci. Technol. 2010, 44(1), 74-79; DOI: 10.1021/es901736t.

(59) Roden, E. E. Fe(III) oxide reactivity toward biological versus chemical reduction. Environ. Sci. Technol. 2003, 37, 1319-1324; DOI: 10.1021/es026038o.

(60) Roden, E. E.; Urrutia, M. M. Ferrous iron removal promotes microbial reduction of crystalline iron(III) oxides. Environ. Sci. Technol. 1999, 33, 1847-1853; DOI: 10.1021/es9809859. 
(61) Borch, T.; Masue, Y.; Kukkadapu, R. K.; Fendorf, S. Phosphate imposed limitations on biological reduction and alteration of ferrihydrite. Environ. Sci. Technol. 2007, 41(1), 166-172; DOI: 10.1021/es060695p.

(62) Jia, Y.; Guo, H.; Jiang, Y.; Wu, Y. ; Zhou, Y. Hydrogeochemical zonation and its implication for arsenic mobilization in deep groundwaters near alluvial fans in the Hetao Basin, Inner Mongolia. J. Hydrol. 2014, 518, 410-420; DOI: 10.1016/j.jhydrol.2014.02.004.

(63) Cornell, R.; Schwertmann, U. The Iron oxides: Structure, Properties, Reactions, Occurrence and Uses; Wiley-VCH: Weinheim, 2003.

(64) Hansel, C. M.; Benner, S. G.; Neiss, J.; Dohnalkova, A.; Kukkadapu, R. K.; Fendorf, S. Secondary mineralization pathways induced by dissimilatory iron reduction of ferrihydrite under advective flow. Geochim. Cosmochim. Acta 2003, 67(16), 2977-2992; DOI: 10.1016/S0016-7037(03)00276-X.

(65) Tronc, E.; Belleville, P.; Jolivet, J.-P.; Livage, J. Transformation of ferric hydroxide into spinel by iron(II) adsorption. Langmuir 1992, 8(1), 313-319; DOI: 10.1021/la00037a057.

(66) Jeon, B.; Dempsey, B. A.; Burgos, W. D. Kinetics and mechanisms for reactions of Fe(II) with iron(III) oxides. Environ. Sci. Technol. 2003, 37(15), 3309-3315; DOI: 10.1021/es025900p.

(67) Williams, A. G. B.; Scherer, M. M. Spectroscopic evidence for Fe(II)-Fe ( III ) electron transfer at the iron oxide-water interface. Environ. Sci Technol. 2004, 38(18), 47824790; DOI: 10.1021/es049373g.

(68) Boland, D. D.; Collins, R. N.; Glover, C. J.; Waite, T. D. An in situ quick-EXAFS and redox potential study of the $\mathrm{Fe}(\mathrm{II})$-catalysed transformation of ferrihydrite. Colloids Surf. A 2013, 435, 2-8; DOI: 10.1016/j.colsurfa.2013.02.009.

(69) Hansel, C. M., Benner, S. G.; Fendorf, S. Competing Fe(II)-induced mineralization pathways of ferrihydrite. Environ. Sci. Technol. 2005, 39(18), 7147-7153; DOI: 10.1021/es050666z.

(70) Dzombak, D. A.; Morel, F. M. Surface Complexation Modeling: Hydrous Ferric Oxide; John Wiley \& Sons: New York, 1990.

(71) Mathur, S.; Dzombak, D. A. Surface complexation modeling: Goethite. In: Surface Complexation Modeling 1st Edition, Lützenkirchen J., Ed.; London: Elsevier Ltd. 2006, pp 443-467. 
(72) Pierce, M. L.; Moore, C. B. Adsorption of arsenite and arsenate on amorphous iron hydroxide. Water Res. 1982, 16(7), 1247-1253; DOI: 10.1016/0043-1354(82)90143-9.

(73) Gustafsson, J.; Bhattacharya, P. Geochemical modelling of arsenic adsorption to oxide surfaces. In Arsenic in Soil and Groundwater Environment; Bhattacharya, P., Mukherjee, A. B., Bundschuh, J., Zevenhoven, R., Loeppert, R. H., Eds.; Elsevier B.V. 2007; pp 159-206.

(74) Swedlund, P. J.; Webster, J. G. Adsorption and polymerisation of silicic acid on ferrihydrite, and its effect on arsenic adsorption. Water Res. 1999, 33(16), 3413-3422; DOI: 10.1016/S0043-1354(99)00055-X.

(75) Appelo, C. A. J.; Van Der Weiden, M. J. J.; Tournassat, C.; Charlet, L. Surface complexation of ferrous iron and carbonate on ferrihydrite and the mobilization of arsenic. Environ. Sci. Technol. 2002, 36(14), 3096-3103; DOI: 10.1021/es010130n.

(76) Amstaetter, K.; Borch, T.; Larese-Casanova, P.; Kappler, A. Redox transformation of arsenic by Fe(II)-activated goethite (r-FeOOH). Environ. Sci. Technol. 2010, 44(1), 102-108; DOI: 10.1021/es901274s.

(77) Kirk, M. F.; Roden, E. E.; Crossey, L. J.; Brealey, A. J.; Spilde, M. N. Experimental analysis of arsenic precipitation during microbial sulfate and iron reduction in model aquifer sediment reactors. Geochim. Cosmochim. Acta 2010, 74(9), 2538-2555; DOI: 10.1016/j.gca.2010.02.002.

(78) Kocar, B. D.; Borch, T.; Fendorf, S. Arsenic repartitioning during biogenic sulfidization and transformation of ferrihydrite. Geochim. Cosmochim. Acta 2010, 74(3), 980-994; DOI: $10.1016 /$ j.gca.2009.10.023.

(79) Rathi, B.; Neidhardt, H.; Berg, M.; Siade, A.; Prommer, H. Processes governing arsenic retardation on Pleistocence sediments: Adsorption experiments and model-based analysis. Water Resour. Res. 2017, 53, 4344-4360; DOI: 10.1002/2017WR020551.

(80) Schittich, A.R.; Wünsch, U.J.; Kulkarni, H.V.; Battistel, M.; Bregnhøj, H.; Stedmon, C.A.; McKnight, U.S. Investigating fluorescent organic-matter composition as a key predictor for arsenic mobility in groundwater aquifers. Environ. Sci. Technol. 2018, 52(22), 13027-13036; DOI: 10.1021/acs.est.8b04070.

(81) Zobrist, J.; Dowdle, P. R.; Davis, J. A.; Oremland, R. S. Mobilization of arsenite by dissimilatory reduction of adsorbed arsenate. Environ. Sci. Technol. 2000, 34, 47474753; DOI: 10.1021/es001068h. 
(82) Islam, F. S.; Gault, A. G.; Boothman, C.; Polya, D. A.; Charnock, J. M.; Chatterjee, D.; Lloyd, J. R. Role of metal-reducing bacteria in arsenic release from Bengal delta sediments. Nature 2004, 430, 68-71; DOI: 10.1038/nature02638.

(83) Burnol, A.; Garrido, F.; Baranger, P.; Joulian, C.; Dictor, M.-C.; Bodenan, F.; Morin, G.; Charlet, L. Decoupling of arsenic and iron release from ferrihydrite suspension under reducing conditions: a biogeochemical model. Geochem. Trans. 2007, 8(12), 1-18; DOI: 10.1186/1467-4866-8-12.

(84) Hansel, C. M. Bacterial and Geochemical controls on the reductive dissolution and secondary mineralization of iron (hydr)oxides. Ph.D. Dissertation, Stanford University, Stanford, CA, 2004.

(85) Hansel, C. M.; Learman, D. R.; Lentini, C. J.; Ekstrom, E. B. Effect of adsorbed and substituted $\mathrm{Al}$ on $\mathrm{Fe}(\mathrm{II})$-induced mineralization pathways of ferrihydrite. Geochim. Cosmochim. Acta 2011, 75(16), 4653-4666; DOI: 10.1016/j.gca.2011.05.033.

(86) Ye, Y. Chiogna, G.; Cirpka, O. A.; Grathwohl, P. Rolle, M. Experimental investigation of compound-specific dilution of solute plumes in saturated porous media: 2-D vs. 3-D flow-through systems. J. Contam. Hydrol. 2015a, 172, 33-47; DOI: 10.1016/j.jconhyd.2014.11.002.

(87) Ye, Y.; Chiogna, G.; Cirpka, O. A.; Grathwohl, P.; Rolle, M. Enhancement of plume dilution in three-dimensional porous media by flow-focusing in high-permeability inclusions. Water Resour. Res. 2015b, 51, 5582-5602; DOI: 10.1002/2015WR016962.

(88) Li, L.; Salehikhoo, F.; Brantley, S. L.; Heidari, P. Spatial zonation limits magnesite dissolution in porous media. Geochim. Cosmochim. Acta 2014, 126, 555-573; DOI: 10.1016/j.gca.2013.10.051.

(89) Muniruzzaman, M.; Haberer, C. M.; Grathwohl, P.; Rolle, M. Multicomponent ionic dispersion during transport of electrolytes in heterogeneous porous media: Experiments and model-based interpretation. Geochim. Cosmochim. Acta 2014, 141, 656-669; DOI: 10.1016/j.gca.2014.06.020.

(90) Wen, H.; Li, L. An upscaled rate law for mineral dissolution in heterogeneous media: The role of time and length scales. Geochim. Cosmochim. Acta 2018, 235, 1-20; DOI: 10.1016/j.gca.2018.04.024.

(91) Battistel, M.; Muniruzzaman, M.; Onses, F.; Lee, J.; Rolle, M. Reactive fronts in chemically heterogeneous porous media: Experimental and modeling investigation of pyrite oxidation. Appl. Geochem. 2019, 100, 77-89; DOI: 10.1016/j.apgeochem.2018.10.026. 